\title{
The role of the state in ensuring digital transformation of banking sector
}

\author{
Yulia B. Bubnova ${ }^{1, *}$ \\ ${ }^{1}$ Baikal State University, 11, Lenin Str., Irkutsk, Russia
}

\begin{abstract}
In the age of digital technologies, the main factor of competitiveness in the financial market is "digital capital". Using developments in the field of information technology, banks change the format and methods of providing their products and services, participate in the provision of services that are not typical for them. In such circumstances, banks have to completely transform their business and build it on the basis of platforms. Changes in the operating conditions of the financial market entail changes in the rules of conduct on it and approaches to its regulation. Investing in technologies, creating and developing ecosystems require significant financial investments from banks, which not all banks can afford. This research analyzes the possibilities of using digital capital by the most successful Russian banks in building and developing ecosystems. The main models of banking ecosystems used in Russian practice are systematized. The necessity of state participation in financial support of the digital transformation of the banking sector is justified. The steps taken by the Bank of Russia in this direction are evaluated. The article summarizes the Bank of Russia's efforts to develop approaches to financial market regulation to ensure information security and prevent financial isolation. Steps taken by the regulator to ensure an equal access to financial services for all citizens, equal opportunities for competition of various financial market players.
\end{abstract}

Keywords: banks, financial market, ecosystem, digital technology, regulation

\section{Introduction}

The Russian banking sector is the largest user of digital technologies and the main driver of digital transformation of the entire economy. The financial services market has recently become very attractive for many participants, as it is becoming more and more technological. Services that still recently were provided only by credit organizations are becoming popular among companies that use modern mobile and Internet technologies. Telecom operators are responsible for instance issues. Customer creditworthiness assessment (online scoring) is carried out by specialized companies, for example, "Direct Credit" and "Gridfore". In the sphere of crediting of the enterprises of small and medium business, banks compete with technologically advanced platforms: "City money" and "Moulding". Many financial services are provided by such companies as "UK FinEx Plus" and "Cindicator", "Optiacs", "Unicombay", "Simple Invest", etc.

The emergence of a new format of banks - nonbanks - in the last decade also poses a threat to the functioning of banks in the traditional format. The long and successful work of "Tinkoff Bank" confirms this. Among the newcomers who have proven themselves in the banking market, we can mention "Roketbank" - one of the first mobile banking services in Russia, created in 2012. Since 2015, "Touch Bank" has been operating in an online format as a retail direction of "OTP Bank". "Modul Bank" has been operating in a new format since 2016. "Tochka Bank", as a branch of "FC Otkritie", is also a representative of non-banks. The interesting project in the field of a new format of banking services in messengers is "TalkBank" - a resident of the SKOLKOVO Innovation center.

In the works of many domestic $[1,3,5,7,16]$ and foreign authors $[14,15]$, the influence of technology on the financial sector in general and the banking sector in particular is revealed. Digitalization has significantly affected the marketing activities of banks, the ways of organization and conducting business, changed the structure of banks' expenses, reducing management, organizational expenses, costs associated with storing and transporting cash, the costs of receiving, processing and storing information, and provoked an increase in the scale of operations. Many banks, using their established customer bases and having professionals in the field of information technology, try to create customized products and services for both existing and potential customers, create and develop ecosystems.

Building an ecosystem and developing the necessary technologies to implement such solutions is not an easy task for many banks, as it requires highly qualified personnel, strong technical support and huge investments in technology. So, Sberbank has spent $\$ 1$ billion on buying assets for its ecosystem for the last three years

Corresponding author: 23bal@mail.ru 
(about $3 \%$ of its profit during this time). For many banks, with a reduced financial result, such investments are simply impossible. But there are some options here too. If the Bank cannot afford to create such technologies on its own, it can join the existing ecosystem. The model options may be different. Many small regional banks have followed the latter way. Joining groups of larger credit organizations, they occupy their own niche there and develop due to the help of the parent company.

On the one hand, this increases concentration in the banking sector, which can lead to less competition, and, consequently, is the reason for a decrease in the quality of services. However, according to research conducted by "Ernst \& Young", an international leader in the field of audit, taxation, transaction support and consulting (hereinafter - E\&Y), the Russian banks occupy leading positions in the implementation of new technological solutions. In the field of digitalization of their business processes, Russian banks are not inferior, and in some areas they are ahead of their American and European counterparts. Domestic credit organizations benefit from flexibility and ease of use, including online banking systems, contactless payment services, and so on.

Banks with state participation are the driving force behind such changes. The infusion of public investment in this sector has given impetus to the development of technological financial services. It worth noting that for a long time our banking system has been developing based on the experience of Western banks. But in the terms of sanctions, our authorities paid more attention to the experience of forming the Chinese banking system. In China, the share of state-owned banks (banks financed by the government) is very high. When forming its banking system 30 years ago, China did not abandon state-owned banks, but gave them the authority to develop and finance technological projects. The result is obvious today. China is the largest economy and one of the most high-tech powers. It was his experience that provoked the creation of the FINTECH Corporation by the Bank of Russia and the infusion of a huge amount of funds to support technological projects in the financial sector. Nowadays, the largest banks (mainly with state and foreign participation) show significant success in the field of technological financial services.

The research conducted by the E\&Y company in 27 global markets confirms that Russia is one of the world leaders in the penetration of FINTECH services (figure 1).

The level of its penetration is $82 \%$, which is significantly higher than the global total, only China and India (having $87 \%$ ) passed ahead. Compared to 2017, the index has grown almost doubled.

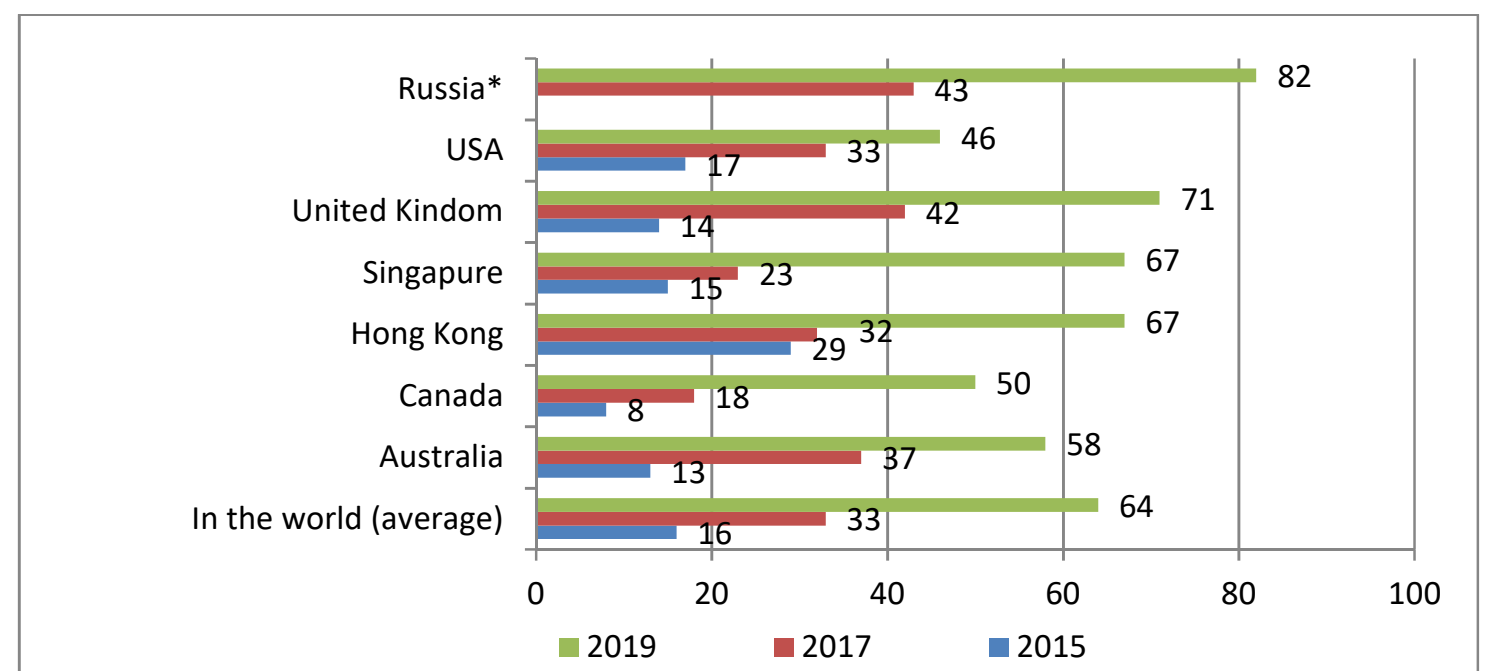

Figure 1. The comparison across countries of the level of financial technology penetration in 7 markets in the period of 2015-2019, $\%[17]$

* In Russia in 2015, the level of penetration was not determined

\section{Problem Statement}

The introduction of digital technologies saves transaction costs, creating new potential, and at the same time new requests and requirements to the market, accelerates business. As a result, the life span of not only the product, but also the company is shortened. So, in the Standard \& Poor 500 rating, the life span of large corporations has been reduced from 60 years to 18. And according to Forbes analysts, over the past fifty years, only in the United States of America, the life cycle of large companies on average has decreased five times from 75 to 15 years $\mathrm{x} 4 \mathrm{~b}$.
Yesterday's competitors of banks can become partners. This is what happened to companies that provide e-money transfer services, which eventually became subsidiaries of banks, and the banks themselves began to transfer funds without opening an account.

It should be noted that a new high-quality product, a more technological process provide only a temporary competitive advantage. In order to remain competitive and maintain their position in the market (or just stay in the market), banks have to be able to apply a new more effective model, change it and refine it in time. All this forces banks to constantly change and rebuild and it means to be innovative. 
Such changes require large financial investments that only large banks can make. In this regard, the Bank of Russia should create equal opportunities for all financial market participants to switch to the digital format and ensure legal regulation of new banking business formats.

\section{Research Questions}

Changes in the operating conditions of the financial market entail changes in the conditions of competition in it and the rules of its regulation.

1. Today for the banking sector the displacement factors of competitiveness take place in the direction and initiative of its employees and prospective strategic planning. The Bank is more interested in how to serve its customers at a higher qualified level, offering a more technologically advanced service that allows you to quickly satisfy as many needs of its customers as possible.

2. To make a profit from the use of digital technologies, banks have to radically change their business models and be very mobile. A new business model based on the network effect can be a platform that involves its joint use by all partners. Today, the largest Russian banks are beginning to widely use open interfaces, create and develop ecosystems. This business model makes the market more mobile and transparent. But its functioning can become the basis for price discrimination.

3. In maintaining and developing a competitive environment in the financial market, the role of the regulator that sets the rules and monitors their implementation is important. Moreover, we need financial support from the state in implementing largescale projects that will allow us to modernize the entire financial services sector.

\section{Purpose of the Study}

The purpose of this study is to justify the increasing role of the state in ensuring the digital transformation of the banking sector. The Bank of Russia's efforts should be aimed at maintaining a competitive environment in the financial market, providing financial support for the introduction of new technologies, and transforming the banking business. Special attention should be paid to the development and implementation of new rules of conduct for financial market participants, and also monitoring their compliance.

\section{Research Methods}

In the course of the research, such methods as analysis and synthesis, the grouping method and the graphical method were used. The analysis and synthesis were used in the consideration of the concept of digital capital, in generalizing the practice of forming banking ecosystems, activities carried out by the Bank of Russia to maintain a competitive environment in the financial market, the introduction of new technologies and the transformation of banking business. The grouping method was used to identify the main ecosystem models. The graphical method was used to visually compare countries by the level of financial technology penetration.

\section{Findings}

The penetration of digital technologies into all spheres of human activity requires banks to develop new products and services, new methods and models of interaction with customers. The source of income for the Bank and its competitive advantage is knowledge of the problems and needs of customers, the technological ability to quickly and efficiently create and provide services. Analysts of the international consulting company "McKinsey \& Company identified the resources needed to develop new products and services in the digital economy as "digital capital" [2]. According to some authors, this form of capital includes both traditional assets (servers, routers, web portals and basic software that allows working on the Internet) as well as intangible assets (unique developments that contribute to the development of digital technologies, opportunities provided by technologies such as Big Data that contribute to the growth and expansion of business, etc.) [8] defines digital capital as "a set of internalized abilities and abilities" (digital competencies), as well as "external resources" (digital technologies) that can be historically accumulated and transferred from one field of activity to another. The contribution of digital capital to the creation of a new product is more significant than labor [11].

Another important factor in the competitiveness of banks is the creativity of employees. In the context of digital transformation and the digital economy, it is no longer enough to improve human capital to generate super-profits. An important factor becomes the formation of creative capital [12], the possession of which brings a stream of superprofits in the implementation of creative ideas.

To make a profit from the use of digital technologies, banks have to radically change their business models and be very mobile. A new business model based on the network effect is a platform. Multidimensional integration based on a digital platform is a complex process of forming network connections between market entities and allows rational using the potential of interacting entities [13]. Banks are beginning to make extensive use of open interfaces, create and develop ecosystems. A study conducted by the consulting company "Accenture" on 120 major banks confirms this trend: $88 \%$ of the studied banks are aimed at creating partner ecosystems.

Models for building ecosystems can be different. For example, associations of banks within open banking platforms. Banks include their products and services in combined catalogs together with other banks via API (application programming interfaces). An example of such a model can be the transfer system by phone number of Sberbank (number 900), which in 2018 was joined by 4 more banks - "Tinkoff Bank", "Sovcombank", "Proinvestbank" and "SDM-Bank", and 
also 4 companies - "Svyaznoy-Euroset", "MTS", "WebMoney" and "Moby.Money". This competitive advantage of Sberbank has become the basis for price discrimination, which consists in limiting the ability of customers to transfer funds within the Bank. The amounts transferred in excess of the established limits will be charged a $1.5 \%$ commission.

In order to minimize transaction barriers, the Bank of Russia has launched a fast payment system service that allows individuals to transfer money instantly by mobile phone number to themselves or to others in another bank. The absence of the need to enter the recipient's card details and the speed of transfer ensure high of transfers' availability. The Bank of Russia's setting of tariffs for money transfers using this system ensures their low cost. This made it possible for banks that have enabled this service to compete in the field of transfers of funds from individuals with Sberbank.

Another version of the Bank's ecosystem that has become widespread in Russian practice is the creation of a referral platform. This is the principle used by credit organizations within a financial group. All major banks such as "Sberbank", "VTB Bank", "Raiffeisenbank", "Alfa-Bank", etc. are the main credit institutions in the consolidated group. When the client contacts the Bank, he is redirected to other providers of services of his interest that are members of this group. For instance, an application for issuing a car loan received by "Sberbank" will be satisfied with the participation of a subsidiary bank "Setelem Bank" that specializes in car loans. Leasing services for clients within the consolidated groups are provided for-by: Sberbank - "Sberbankleasing", "VTB Bank" - "VTB-leasing", "Alfa-Bank" "Alfa-Leasing", etc.

In addition to financial services (banking, insurance, investment), banks are beginning to introduce nonfinancial services: food delivery, apartment repairs, ticket sales for entertainment events, communication services, etc. Here, the same Sberbank can serve as a striking example. Its ecosystem includes such partners as "Domclick", "Yandex.Money”, "SberMobile", "Beru!", "Okko", "Citymobil", "Delivery Club", "DocDoc".

Portal "Domclick" provides services on search and purchase of apartments in the mortgage. The Service "Yandex.Money" provides electronic transfer services. The virtual operator "SberMobile" provides mobile communication services, thanks to the online marketplace "Beru!" "Sberbank" customers can order goods at a discount, online cinema services are provided by the service "Okko", and taxi services are provided by "Citymobil". With the help of the "Delivery Club" service, you can order food, and also medical services can be ordered through the "DocDoc" service.

Another giant of the banking sector, "VTB Bank", started creating its own ecosystem recently - in 2019. But there are already some developments in the real estate sector. In addition to mortgage programs, the VTB platform will provide services for selecting real estate, financing its purchase or construction, registering real estate, and repairing it. Following the example of Sberbank, "VTB Bank" launched its own Telecom operator VTB mobile.
"ROSBANK" uses its subsidiary bank "DeltaCredit" (after being renamed "Rosbankdom") as a platform for developing services around mortgages: it provides services for registration in Roseestr, real estate insurance, interior design, sale and delivery of furniture, and cleaning of premises.

"Tinkoff Bank", the most ambitious bank in the digital format, has been developing its ecosystem since 2013. Provides insurance services through the "Tinkoff Insurance" service, investment services through "Tinkoff Investments", clients of the small and medium-sized business segment can perform business registration, settlement and cash services, acquiring, and receive loans using the "Tinkoff Business" and "Tinkoff Payment" services. The Bank also has a virtual Telecom operator "Tinkoff mobile". The "Tinkoff Bank" ecosystem includes partners such as "Rambler.Checkout" and "Afisha-Restaurants".

Another option is to synchronize the banking infrastructure with key stages of the client's life. For example, in the case of an individual entrepreneur and a legal entity: financing the implementation of an idea (startups), supporting and supporting the business, expanding it, entering new markets, and so on. The system tracks the occurrence of such stages and provides information about this to partners within the framework of cooperation agreements. A striking example of such successful work can be the ecosystem built for small and medium-sized businesses by "Tinkoff Bank".

The use of such models, which take into account various customer requests, makes the market more mobile and more transparent. But the functioning of such a model is associated with a number of problems that are common to all open systems.

Along with competitive advantages, this can also be a serious reason for price discrimination. An example of a money switching barrier for consumers is the current practice of banks charging different amounts of commission for internal and external money transfers. According to a study conducted by the FAS of Russia together with the Bank of Russia, there is usually no commission for transfers within banks, but the average commission for external transfers is $1.5 \%$, and in some cases it can reach 3-4\% of the transfer amount. The current pricing practice restricts the consumer's ability to freely move their funds to a financial service provider that provides the best offer, and, thus, negatively affects competition in the financial market.

In maintaining and developing a competitive environment in the financial market, the role of the regulator that sets the rules and monitors their implementation is important. That is why the Bank of Russia, when developing its financial market development strategy, has identified competition as one of the four main areas of financial market development.

To ensure the dynamic development of financial services, increase competition, and protect the rights and interests of all financial market participants, including consumers, financial organizations, and FINTECH companies, the Bank of Russia opened a separate activity development of open API, in the financial technology development Association [17], established 
jointly with major Russian financial organizations in December 2016 [9]. This direction is engaged in studying and testing the possibilities of open banking in the financial market. This is about ensuring access for all market participants to open information from credit institutions: the location and opening hours of ATMs, branches, POS terminals, etc. It is also possible for third parties to access confidential information about the Bank's clients (their accounts) in order to provide new financial products and services.

The main issue is the development of approaches to regulation in this area. The development of open banking raises the regulator's concerns related to conflicts of interest, uneven distribution of influence and increased financial isolation. The convenience, speed, and simplicity of transactions can be worth losing control of your data.

That is why the Bank of Russia initiated a regulatory sandbox (a mechanism for piloting and modeling the processes of new financial services and technologies in an isolated environment that require changes in legal regulation) as part of the implementation of the main directions for the development of financial technologies for the period 2017-2020.

Moreover, in August 2019, the Bank of Russia coordinated a pilot project in the field of API for the integration of banking services within the Eurasian economic Union. 20 credit organizations were invited to this event.

The success of many major banks, which determine the vector of transformation of the financial sector, is impossible without the financial support of the state. The Bank of Russia is taking the necessary steps to do this. In addition to the FINTECH Association, which works with major banks to develop and test the latest technologies in the banking sector, there is also the State Corporation of development "VEB.RF". This Institute operates on the basis of the Federal law "About the State Corporation of development "VEB.Russia" and in partnership with Russian commercial banks are engaged in financing projects aimed at the development of infrastructure, innovation and high technologies.

In order to ensure that all individuals can access banking services remotely, the Bank of Russia has initiated a remote identification mechanism that allows individuals to receive financial services remotely by verifying their identity using biometric personal data at any Bank. After registering in the Unified identification and authentication system (USIA) and the Unified biometric system, a citizen can remotely contact a new Bank to receive financial services from any place at any time.

This procedure makes it possible to increase the availability of financial services and reduce the costs of citizens moving to other financial organizations.

In addition, the "Digital profile of a citizen" infrastructure created with the participation of the Bank of Russia will allow for convenient, secure and fast data exchange between citizens, the state and business in a "one-stop shop" format. The creation of this platform will facilitate competitive access to data, as well as the transfer of services to digital format.
An important project implemented by the Bank of Russia in this context is the "Marketplace" project. It provides an opportunity for individuals to distantly receive a wide range of financial services from the largest possible range of financial organizations, as well as to record information about concluded transactions in a single financial transaction Registrar. The creation of this type of infrastructure will expand the opportunities for financial organizations that do not have a wide branch network and large-scale infrastructure for remote services to effectively compete with market leaders. At the same time, the marketplace will significantly reduce switching barriers for consumers.

\section{Conclusion}

As a result of the research, new factors that ensure the competitiveness of banks in the financial market were identified. The main one is "digital capital" - resources (tangible and intangible assets) that are necessary for the development and promotion of new products and services in the digital economy. Human capital becomes an advantage if Bank employees are endowed with initiative and creativity, and are guided by current trends, both in the field of financial services and in the field of new digital technologies. New created or purchased products or technological processes implemented should be able to adapt and modify so that the Bank can change its business model, adapt it to changing environmental conditions and new customer needs, without compromising the quality of existing services. Developing the Bank's ecosystem may be an option. Models for building ecosystems can be different: from combining banks, banks and financial and non-financial structures, to synchronizing your own business with your clients business.

To ensure the availability of digital capital and the development of ecosystems, banks need large financial investments in highly qualified personnel and powerful technical support in information technologies. Even large banks cannot afford such infusions. State support in this regard is very important. To ensure the dynamic development of the financial market, its transition to a digital format, there is State Corporation "VEB.RF", FINTECH Associations that actively participate in the development and testing of the latest technologies in the banking sector.

Another important direction for the development of the financial market in modern conditions is the development of approaches to regulation in this area. The widespread of open banking exacerbates the problems of information security and financial isolation. In this direction, the Bank of Russia is implementing a pilot project - "a regulatory sandbox". To ensure remote access of individuals to financial services, the Bank of Russia initiated the creation of a mechanism for remote identification, a "Digital profile of a citizen", and launched the "Marketplace" project. The development of this kind of infrastructure will provide equal opportunities for competition between financial market players of various scales of activity. 


\section{Acknowledgments}

The reported study was funded by RFBR, project number No. 19-010-00100-A.

\section{References}

1. E.V. Ageeva, M.A. Afanasyeva et al. Digitalization of the financial and credit sphere in modern Russia (Direct-Media, Moscow; Berlin, 2019)

2. J. Bughin, J. Manyika. Measuring the full impact of digital capital (2018). Retrieved from: https://www.mckinsey.com/industries/high-tech/ourinsights/measuring-thefull-impact-of-digitalcapital\#0

3. O. Ermolenko. Development of the banking sector on the basis of modern technologies of service. Sci. bull. of the South. Inst. of Manag., 2, 26-30 (2018)

4. O. Konovalov. Organizational anatomy: five reasons why companies die (2017). Retrieved from: https://www.forbes.ru/biznes/340993-gazprom-naneve-dve-treti-administracii-monopolii-uzhe-vpeterburge

5. V. Kosarev, G. Iarajuli. Ecosystem as a new model of the Bank's development. Finan. Mark. and banks, 1, 58-62 (2020)

6. S. Matveyevskoye. FINTECH and development banks: impact on economic growth (for example, VEB of Russia). Finan. Mark. and banks, 1, 105-109 (2020)

7. E. Okomina, M. Matveeva. The trends of «digitalization» of the banking sector. Syst. Anal. \& Mathem. Model., 1(2), 47-53 (2020)

8. M. Ragnedda. Conceptualizing Digital Capital. Telemat. and Inform., 35, 2366-2375 (2018)

9. Report for public consultation (2017). Development of open API (OpenAPI) on the financial market. Retrieved from: http://www.cbr.ru/content/document/file/50679/cons ultation_paper_171229.pdf

10. A. Rukavishnikova. Role and Importance of Artificial Intelligence in Russian Banking Industry. Glob. \& reg. res., 1(1), 58-61 (2019)

11. M. Safronchuk. Influence of information economy and globalization on factors of economic growth. Bull. of the Acad., 4, 31-34 (2014)

12. M. Safronchuk. Influence of digital transformation on business and the business environment. Econ. and manag.: probl., solut., 2(3), 38-44 (2018)

13. V. Samarukha, T. Krasnova, A. Dulesov. Integrating Digital Production Systems. Bull. of Baikal State Univ., 2(30), 309-317 (2020)

14. P. Vigna, M.J. Casey. The Age of Cryptocurrency: How Bitcoin and the Blockchain Are Challenging the Global Economic Order (Picador, USA, 2016)

15. G. Westerman, D. Bonnet, A. McAfee. Leading Digital: Turning Technology into Business Transformation. (Harvard Busin. Rev. Press, 2014)
16. M. Zhigas, S. Kuzmina. Blockchain and Decentralized Money System: Principles of Building and Ways of Its Development. Bull. of Baikal State Univ., 1(3), 79-88 (2020)

17. FINTECH services penetration index (2019). Retrieved from: https://www.ey.com/Publication/ vwLUAssets/ey-fai-2019-rus/\$FILE/ey-fai-2019rus.pdf 